\begin{tabular}{l} 
Thabiea: Journal of Natural Science Teaching \\
Program Studi Tadris Ilmu Pengetahuan Alam \\
$\begin{array}{l}\text { Institut Agama Islam Negeri Kudus } \\
\text { http://journal.stainkudus.ac.id/index.php/Thabiea } \\
p \text {-issn: } 2580-8974, e-i s s n: 2655-898 x\end{array}$ \\
\hline
\end{tabular}

\title{
Peningkatan Soft Skill Kerja Sama dan Pemahaman Konsep Peserta Didik Kelas VIII MTs Ma'arif NU 1 Patikraja pada Mata Pelajaran IPA Melalui Penerapan Model Pembelajaran Problem Based Learning
}

\author{
Laely Mahmudaha ${ }^{\mathrm{a}, 1^{*}}$ \\ a MTs Ma'arif NU 1 Patikraja Banyumas
}

${ }^{1}$ laely_mahmudah@yahoo.co.id*

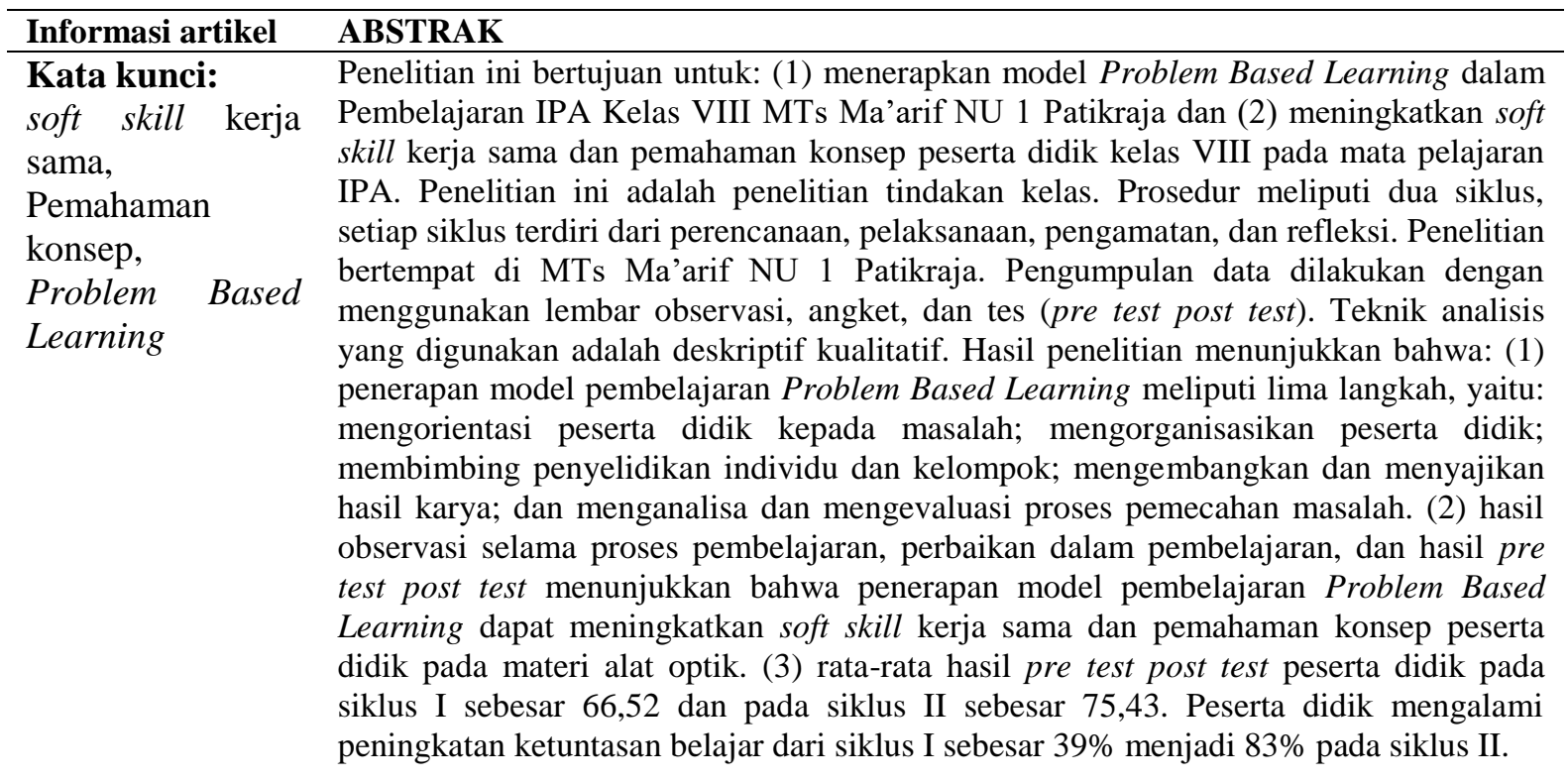

\begin{tabular}{ll}
\hline & ABSTRACT \\
\hline Key word: & Enhancement of Collaboration Soft Skill and Concepts Understanding of Students \\
Soft skills & Grade VIII of MTs Ma'arif NU 1 Patikraja in Science Subjects Through Application \\
cooperation, & of Problem Based Learning Learning Models. This study aims to: (1) apply the \\
understanding & Problem Based Learning in Science Grade VIII model of MTs Ma'arif NU 1 Patikraja \\
concepts, & and (2) improve the soft skills of cooperation and understanding the concepts of class \\
Problem Based & VIII students in science subjects. This research is a classroom action research. The \\
Learning & procedure includes two cycles, each cycle consisting of planning, implementation, \\
& observation, and reflection. The study took place at MTs Ma'arif NU 1 Patikraja. Data \\
& collection is done using observation sheets, questionnaires, and tests (pre test post \\
& test). The analysis technique used is descriptive qualitative. The results of the study \\
& show that: (1) the application of the Problem Based Learning model includes five \\
& steps, namely: orienting students to problems; organize students; guiding individual \\
& and group investigations; develop and present the work; and analyze and evaluate the \\
& problem solving process. (2) the results of observations during the learning process, \\
& improvements in learning, and the results of the pre test post test showed that the \\
& application of the Problem Based Learning model can improve the soft skills of \\
cooperation and understanding the concepts of students in optical instrument material. \\
(3) the average pre-test results of post-test students in the first cycle amounted to 66.52 \\
and in the second cycle was 75.43. Students experience increased learning \\
completeness from the first cycle of $39 \%$ to 83\% in cycle II.
\end{tabular}

Copyright (C) 2019 Institut Agama Islam Negeri Kudus. All Right Reserved 


\section{Pendahuluan}

Kurikulum merupakan hal yang mendasar dalam pembelajaran. Di Madrasah Tsanawiyah (MTs) Ma'arif NU 1 Patikraja pada tahun pelajaran 2015/2016 melaksanakan Kurikulum Tingkat Satuan Pendidikan (KTSP). Materi kelas VIII semester genap pada KTSP semuanya Fisika, sehingga hal ini menimbulkan beberapa kendala. Peserta didik kurang tertarik dengan banyaknya rumus-rumus Fisika beserta soal-soal hitungannya. Guru sering menggunakan metode pembelajaran yang monoton, peserta didik diminta untuk mengerjakan latihan soal hitungan, dampaknya peserta didik menjadi bosan.

Pembelajaran yang menyenangkan dapat meningkatkan pemahaman konsep peserta didik terhadap mata pelajaran IPA. Salah satunya dengan cara praktikum di laboratorium. Namun, karena sarana prasarana alat-alat praktikum yang minim serta belum tersedianya ruang laboratorium di MTs Ma'arif NU 1 Patikraja, peserta didik jarang sekali melakukan praktikum. Guru hanya bisa mendemonstrasikan alat peraga yang dimiliki pada materi tertentu.

Hasil ulangan harian peserta didik pada materi pokok bunyi rata-rata 67,00 dan masih di bawah KKM (Kriteria Ketuntasan Minimal). Kondisi ini dapat disebabkan antara lain karena proses pembelajaran yang bersifat teacher center, peserta didik kurang aktif dalam pembelajaran. Perlu adanya perbaikan dalam proses pembelajaran, diawali dengan perencanaan yang tepat disesuaikan dengan sarana prasarana yang ada.

Salah satu cara memperbaiki proses pembelajaran adalah dengan menerapkan metode pembelajaran yang bersifat student center (Collete \& Chiappetta, 1994). Peserta didik dapat menemukan konsep dari aktivitas sendiri. Model pembelajaran Problem Based Learning (PBL) dapat dijadikan salah satu alternatif untuk mengaktifkan peserta didik dalam pembelajaran IPA materi alat optik.

Lima tahap model pembelajaran Problem Based Learning menurut Hosnan (2014: 302) yaitu mengorientasi peserta didik terhadap masalah, mengorganisasi peserta didik untuk belajar, membimbing penyelidikan individual maupun kelompok, mengembangkan dan menyajikan hasil karya (diskusi), menganalisis dan mengevaluasi proses pemecahan masalah. Model Problem Based Learning yang akan dilaksanakan berupa langkah-langkah pembelajaran yang dapat meningkatkan pemahaman konsep peserta didik dan soft skill kerja sama, karena dilakukan secara berkelompok. Berdasarkan hal tersebut, perlu adanya penelitian tentang Peningkatan Soft skill Kerja sama dan Pemahaman Konsep Peserta Didik Kelas VIII MTs Ma'arif NU 1 Patikraja pada Mata Pelajaran IPA Melalui Penerapan Model Problem Based Learning.

Penelitian tindakan kelas ini bertujuan untuk: (1) Menerapkan model Problem Based Learning dalam pembelajaran IPA Kelas VIII MTs Ma'arif NU 1 Patikraja dan (2) Meningkatkan soft skill kerja sama dan pemahaman konsep peserta didik kelas VIII pada mata pelajaran IPA.

\section{Metode penelitian}

Subyek penelitian adalah peserta didik kelas VIII D di MTs Ma'arif NU 1 Patikraja. Pemilihan tersebut dilakukan atas pertimbangan bahwa peserta didik kelas VIII D cenderung pasif saat belajar IPA. Guru juga ingin mengembangkan 
pembelajaran yang efektif dan efisien khususnya pada materi alat optik.

Penelitian ini dilaksanakan di MTs Ma'arif NU 1 Patikraja, karena peneliti adalah guru IPA di MTs Ma'arif NU 1 Patikraja. Subjek penelitian adalah siswa kelas VIII D MTs Ma'arif NU 1. Penelitian meliputi pembuatan proposal, pelaksanaan, dan pelaporan.

\section{Hasil dan pembahasan}

Permasalahan pada pembelajaran IPA di kelas VIII D adalah aktivitas belajar peserta didik di kelas kurang kondusif, pembelajaran masih bersifat teacher center dan soft skill kerja sama peserta didik masih rendah. Pemahaman konsep peserta didik dari hasil pre test rerata 58,04 masih rendah, karena KKM IPA 72. Untuk itu perlu perlu model pembelajaran salah satunya model PBL yang bisa mengaktifkan siswa. PBL mengajarkan pada siswa untuk aktif dan berfikir kritis dan kreatif. Tujuan dari penelitian ini adalah untuk menerapkan model Problem Based Learning dalam pembelajaran IPA dan untuk meningkatkan soft skill kerja sama dan pemahaman konsep peserta didik pada materi alat optik. Sesuai dengan tujuan penelitian, maka dilakukan penelitian tindakan kelas yang terdiri dari beberapa siklus, yang dalam pelaksanaannya ada dua siklus. Tindakan yang dilakukan pada siklus I dan II merupakan hasil kolaborasi antara guru (peneliti) dan teman sejawat (guru IPA) sekaligus observer.

Langkah-langkah model pembelajaran Problem Based Learning yang diterapkan dalam penelitian ini mengacu pada Kemendikbud (2013: 300). Pelaksanaannya terdiri dari lima tahap yaitu:

1. Orientasi peserta didik kepada masalah
Guru menjelaskan tujuan pembelajaran dan menjelaskan logistic yang dibutuhkan. Guru juga memotivasi peserta didik untuk terlibat aktif dalam pemecahan masalah yang dipilih.

2. Mengorganisasikan peserta didik Pada tahap ini guru membantu peserta didik mendefinisikan dan mengorganisasikan tugas belajar yang berhubungan dengan masalah tersebut.

3. Membimbing penyelidikan individu dan kelompok

Guru mendorong peserta didik untuk mengumpulkan informasi yang sesuai, melaksanakan diskusi atau eksperimen untuk mendapatkan penjelasan dan pemecahan masalah. Bimbingan dan dorongan ini akan menjadikan siswa aktif dan kreatif (Fikri, 2019).

4. Mengembangkan dan menyajikan hasil karya

Guru membantu peserta didik dalam merencanakan dan menyiapkan karya yang sesuai seperti laporan hasil diskusi.

5. Menganalisa dan mengevaluasi proses pemecahan masalah

Pada akhir pembelajaran dilakukan evaluasi hasil belajar tentang materi alat optik dan meminta kelompok mempresentasikan hasil kerjanya. Guru juga melakukan diskusi dengan guru IPA (observer) untuk mengevaluasi proses pembelajaran sebagai refleksi terhadap pembelajaran yang telah berlangsung.

Peserta didik kelas VIII D yang berjumlah 23 menjadi subyek penelitian. Materi yang digunakan pada penelitian ini adalah alat optik yang meliputi mata, kamera, lup, mikroskop, dan teleskop. Instrumen yang digunakan pada penelitian ini adalah rencana pelaksanaan pembelajaran (RPP), LKPD, soal pre test 
dan post test, lembar observasi soft skill kerja sama, lembar observasi keterlaksanaan pembelajaran, dan angket respon peserta didik terhadap pembelajaran dengan menggunakan model Problem Based Learning.

Penelitian tindakan kelas ini dilakukan untuk meningkatkan soft skill kerja sama dan pemahaman konsep peserta didik kelas VIII MTs Ma'arif NU 1 Patikraja. Seperti telah dijelaskan sebelumnya bahwa soft skill kerja sama adalah kemampuan peserta didik untuk bekerja sama dalam kelompok dengan indikator menghargai pendapat peserta didik, berpartisipasi aktif dalam kelompok, tanggung jawab, berbagi informasi dan pengetahuan (Kasmadi, 2013). Pemahaman konsep adalah penguasaan pengetahuan atau konsep yang diajarkan (dalam penelitian ini materi tentang alat optik) yang meliputi proses kognitif menafsirkan, mencontohkan, mengklasifikasikan, merangkum, menyimpulkan, membandingkan, dan menjelaskan. Keberhasilan tindakan kelas ini dapat dilihat dari hasil observasi soft skill kerja sama dan pre test post test untuk mengukur pemahaman konsep peserta didik (Thalib, 2013).

Hasil observasi soft skill kerja sama pada siklus I menunjukkan bahwa dalam setiap kelompok masih ada satu atau dua peserta didik yang kurang menghargai pendapat peserta didik lain dalam diskusi kelompok, tidak ikut berpartisipasi aktif dalam kelompok, kurang bertanggung jawab terhadap kelompok, dan tidak mau mencari, apalagi berbagi informasi dan pengetahuan kepada peserta didik dalam satu kelompok. Guru terus melakukan bimbingan dan motivasi agar semua peserta didik dapat berpartisipasi aktif dan bekerja sama dengan baik dalam kelompok masing-masing, karena hal ini berpengaruh terhadap pemahaman konsep peserta didik pada materi alat optik.

Upaya perbaikan pada siklus II untuk meningkatkan soft skill kerja sama dapat dikatakan berhasil, karena hasil observasi soft skill kerja sama menunjukkan peningkatan yang cukup signifikan. Peserta didik menghargai pendapat teman dalam berdiskusi, setiap anggota kelompok berpartisipasi aktif, tanggung jawab yang baik dalam tiap kelompok, dan peserta didik saling berbagi informasi dan pengetahuan dalam kelompok. Peserta didik belajar melalui tugas rumah mencari pengetahuan dari berbagai sumber tentang alat optik, sehingga pada saat diskusi bisa saling berbagi informasi dan pengetahuan.

Tabel 1. Rekapitulasi Pemahaman Konsep Siklus I dan II

\begin{tabular}{|c|l|c|c|c|}
\hline No & $\begin{array}{l}\text { Pencapai } \\
\text { an }\end{array}$ & $\begin{array}{c}\text { Siklus } \\
\text { I }\end{array}$ & Siklus II & $\begin{array}{c}\text { Peningk } \\
\text { atan }\end{array}$ \\
\hline 1 & $\begin{array}{l}\text { Nilai } \\
\text { terendah }\end{array}$ & 50 & 55 & 5 \\
\hline 2 & $\begin{array}{l}\text { Nilai } \\
\text { tertinggi }\end{array}$ & 85 & 95 & 10 \\
\hline 3 & $\begin{array}{l}\text { Nilai rata- } \\
\text { rata }\end{array}$ & 66,52 & 75,43 & 8,91 \\
\hline 4 & $\begin{array}{l}\text { Tuntas } \\
\text { Belajar }\end{array}$ & $39 \%$ & $83 \%$ & $44 \%$ \\
\hline
\end{tabular}

Peningkatan pemahaman konsep peserta didik tentang alat optik dengan menerapkan model pembelajaran Problem Based Learning dapat dilihat pada Tabel 1. Data diambil dari hasil pre test dan post test baik pada siklus I maupun siklus II. Hasil pre test post test juga dapat dilihat pada Gambar 1. Gambar 1 menunjukkan perbandingan rata-rata dan ketuntasan belajar pada siklus I dan siklus II. 


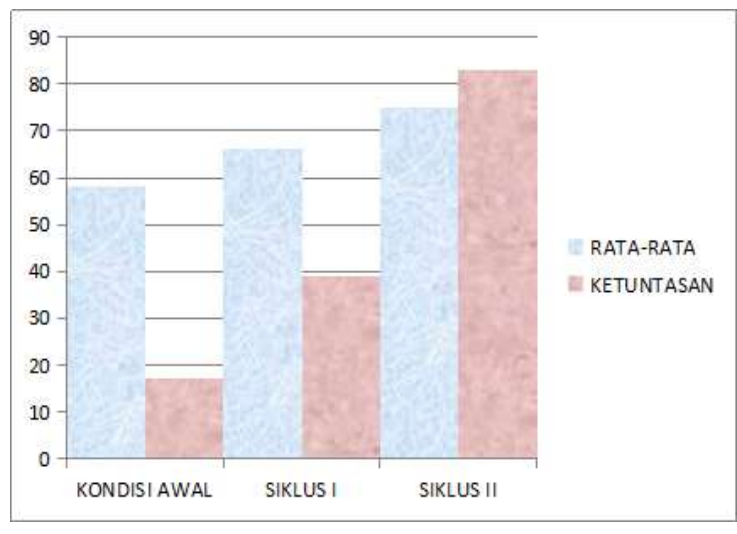

Gambar 1. Perbandingan ketuntasan belajar antar siklus

Model pembelajaran Problem Based Learning yang telah diterapkan efektif untuk meningkatkan soft skill kerja sama dan pemahaman konsep peserta didik. Hal ini senada dengan Hosnan (2014: 308), bahwa model pembelajaran Problem Base Learning memerlukan kerja sama antar peserta didik secara berpasangan atau berkelompok untuk mengidentifikasi informasi dan strategi yang relevan dengan sumber belajar yang relevan untuk menyelesaikan masalah yang ditemukan. Problem Based Learning merupakan pembelajaran yang berpusat pada peserta didik (student center), peserta didik aktif menyelesaikan masalah dan membangun pengetahuannya. Peserta didik belajar langsung dari permasalahan dan meneyelesaikannya sehingga siswa menjadi terampil dalam menghadapi masalah. Keterampilan ini akan menjadikan konsep pemahaman (Yunin, 2014). Peserta didik memahami konsep alat optik karena aktif mencari pengetahuan dan bekerja sama dengan peserta didik untuk menyatukan pendapat difasilitasi oleh guru, sehingga pembelajaran lebih bermakna dan tujuan pembelajaran dapat tercapai.

\section{Simpulan}

Berdasarkan hasil penelitian dan pembahasan yang telah dikemukakan, dapat diambil kesimpulan sebagai berikut:
Penerapan model pembelajaran Problem Based Learning meliputi lima langkah, yaitu: a. Mengorientasi peserta didik kepada masalah; b. Mengorganisasikan peserta didik; c. Membimbing penyelidikan individu dan kelompok; d. Mengembangkan dan menyajikan hasil karya; dan e. Menganalisa dan mengevaluasi proses pemecahan masalah. Hasil observasi selama proses pembelajaran, perbaikan dalam pembelajaran, dan hasil pre test post test menunjukkan bahwa penerapan model pembelajaran Problem Based Learning dapat meningkatkan soft skill kerja sama dan pemahaman konsep peserta didik pada materi alat optik. Rata-rata hasil pre test post test peserta didik pada siklus I sebesar 66,52 dan pada siklus II sebesar 75,43. Peserta didik mengalami peningkatan ketuntasan belajar dari siklus I sebesar 39\% menjadi $83 \%$ pada siklus II.

\section{Referensi}

Collete, A.T. \& Chiappetta, E.L. (1994). Science Instruction in the Middle and Secondary Schools $\left(3^{\text {rd }}\right.$ ed). New York: Macmillan Publishing Company

Fikri., A.A., Ismah, V., \& Paidi, P. (2019). Pengembangan perangkat pembelajaran model Guided Inquiry untuk meningkatkan creative thinking Siswa. Thabiea: Journal of Natural Science Teaching. Vol (1)(01): 1-8.

Hosnan, H. (2014). Pendekatan Saintifik dan Kontekstual dalam Pembelajaran Abad 21 Kunci Sukses Implementasi Kurikulum 2013. Bogor: Penerbit Ghalia Indonesia.

Kasmadi, K. (2013). Membangun Soft skills Anak-anak Hebat Pembangunan Karakter \& Kreativitas Anak. Bandung: Alfabeta.

Kemendikbud. (2013). Materi Pelatihan Guru Implementasi Kurikulum 2013 SMP/MTs IPA. Badan Pengembangan Sumber Daya Manusia Pendidikan dan Kebudayaan dan Penjaminan Mutu Pendidikan, Jakarta. 
Thalib, S. B. (2013). Psikologi Pendidikan Berbasis Analisis Empiris Aplikatif. Jakarta: Kencana Prenamedia Group.

Yunin, N. \& Wardan, S. (2014). Penerapan Model Problem-Based Learning untuk Meningkatkan Keterampilan Berpikir kritis dan Hasil Belajar Siswa. Jurnal pendidikan Vokasi. Vol (4) (1): 125-143 